\title{
Building Material Management Framework for Greener Adaptation Projects
}

\author{
Zarina Isnin, Sabarinah Sh. Ahmad, Zaharah Yahya \\ Faculty of Architecture, Planning \& Surveying, \\ Universiti Teknologi MARA, Shah Alam, 40450 Selangor, Malaysia \\ sabar643@salam.uitm.edu.my
}

\begin{abstract}
The adverse impacts of building materials to sustainability have raised global concerns on the availability of information on hazardous and toxic contents. Data and information on the contents, management and effects were still insufficient. This paper illustrates the issues of building materials information in adaptation projects through critical literature review. In lieu with the current efforts to shift towards greener building practices, improvements are required in the development of building material management during construction, occupancy and operation of building adaptation projects.
\end{abstract}

Keywords: Building adaptation; Building material information; Green construction; Sustainable construction

eISSN 2398-4295 @ 2018. The Authors. Published for AMER ABRA CE-Bs by e-International Publishing House, Ltd., UK. This is an open-access article under the CC BY-NC-ND license (http://creativecommons.org/licenses/bync-nd/4.0/). Peer-review under responsibility of AMER (Association of Malaysian Environment-Behaviour Researchers), ABRA (Association of Behavioural Researchers on Asians) and cE-Bs (Centre for EnvironmentBehaviour Studies), Faculty of Architecture, Planning \& Surveying, Universiti Teknologi MARA, Malaysia.

DOI: http://dx.doi.org/10.21834/ajbes.v3i9.63 


\subsection{Introduction}

In building construction industry, usage of materials is inevitable. Cement, bricks, timber, newer innovative composites, green accredited and other acclaimed materials are used to build and construct buildings, mega structures and others. There is a steady increase in demand for building materials, as the construction industry is growing at a rapid rate almost in every country worldwide. Construction activities not only include new building projects or infrastructure and utilities, but there is a rising demand for improving existing buildings known as "Building adaptation" (Douglas, 2006). It supports the increasing demand for "sustainability" in the built environment. There are also more demands to change the existing building to be more "green" to achieve more efficient usage of energy and water whilst reducing pollution.

The construction process for building adaptation is more complicated. It involves dismantling and partial demolition works that include the removal of building elements, waste materials, relocations of electrical and mechanical supply and provision of safety protection systems. Previous published studies revealed that some building materials produced negative effects on people, the environment and economy. Prior information and documents on the existing building were often unavailable. There were limited information and data on building contents, toxicity, guidelines and proper handling techniques (Sarigiannis \& Mucci, 2009; Wilt et al., 2011); particularly involving hazardous and toxic building materials. Thus, will unknown content of building material still support the "Green" and "Sustainable" construction concepts?

Since building adaptation involves complex activities and threats from exposure to harmful effects of building materials, information on the existing structure including the integration of many health and safety aspects should be made available and accessible to all stakeholders involved in the building adaptation project. This study aims to illustrate through literature review the deficiency of building materials information in adaptation projects. The first objective examines the challenges of building materials in adaptation projects. The second objective illustrates the kind of information that may be required on building materials. The study highlights issues concerning the social and environmental impacts, project management and the economic effects on Malaysian market demand. Findings will lead to a proposed framework outlining the possible information required for building material management to achieve greener adaptation projects.

\subsection{Building Materials in Construction and Adaptation Project}

Building materials are produced, processed, installed, used, maintained and even recycled or reused throughout the lifecycle of a building. Some studies considered the process as "a sustainable system" since the building materials survived or persisted. Economic reports showed that the construction industry is amongst the largest and the most active sectors that contributed to a steady economic growth such as Malaysia (Betts et al., 2011; GBI-Research, 2010). The global construction industry is reported to worth around $\$ 12$ trillion in 2020 dominated by Asia countries. They are expected to increase their share of the market to $\$ 7$ 
trillion (Betts et al., 2011); where a total of $\$ 97.7$ trillion will be spent on construction globally during the next decade and by 2020 , construction will account for $13.2 \%$ of the world's Gross Domestic Product.

There are more building adaptation projects such as alteration, renovation, refurbishment and conservation (Douglas, 2006). Buildings change in physical or functional attributes in adaptation projects. They generate and consume a large amount of resources such as materials, energy and money during the demolition, construction, maintenance and occupancy stages. The changes can produce positive economic effects by increasing the value of completed property. However, do the changes also produce negative effects such as fatal health risks to workers and other building adaptation stakeholders if hazardous building materials and chemicals are used?

Building construction activities are responsible for creating and maintaining a healthy built environment and human health through efficient usage of resources. This process is known as "Sustainable Construction" (SC). The SC process should begin during the planning stage until the building is handed over to the client (Fig. 1). Based from the "Seven principles for SC", all the principles require prior information before effective and efficient actions could take place. For example, toxic substances are required to be eliminated during the construction process. This could be achieved if prior information and knowledge on the content of building materials is available. Furthermore, the process of eliminating the hazardous and toxic substances requires adequate information and knowledge to ensure safety and eliminate unnecessary risks. If some of the unknown building materials in the existing building contain hazardous and toxic substances, will the building adaptation project be considered as "Sustainable construction"?

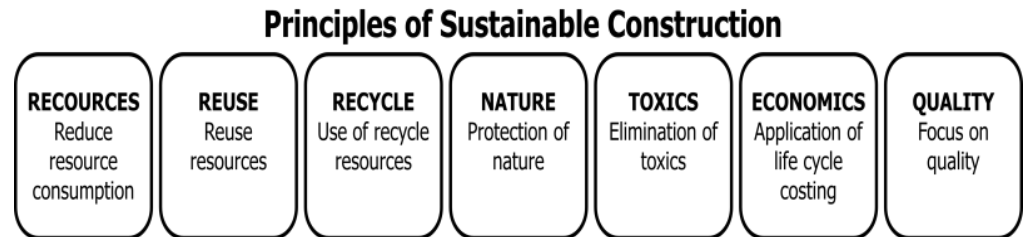

Fig.1: The Principles of Sustainable Construction (Adapted from CIB, 1994 and Kibert, 2008)

\subsection{Risks of Building Materials}

Referring to Fig.1, there is a need to choose non-toxic building materials. However, common building components that are found to be hazardous, toxic and carcinogenic such as asbestos, lead, volatile organic compounds or VOCs, solvents and adhesives are widely used in building construction projects. These materials are dangerous when they became degraded, disturbed or airborne during construction, demolition, reconstruction and during maintenance. They could cause acute and chronic health effects to stakeholders who are exposed to many short and long-term hazards. Some building materials contained high amount of chemicals and heavy metals. They could either contaminate indoor air or pollute 
tap water, thus causing several health-related problems such as: asthma; skin irritations; cancer; impaired child development and birth defects; immune system suppression and cancer. Many new innovative building material products have been developed and will be developed in the future. This may cause insufficient information for health assessments and impacts to the environment, as the research findings and availability of information were always a step behind the newly promoted building products.

Studies indicated that building materials affected the environment and the economy. There were reported cases of pollution and poor air quality from the production of building materials. The prices of several building components were required to be controlled, and there were insufficient supply that led to the slow progress of construction projects. There were also issues on the increasing cost of operating landfill and illegal dumping of waste. Thus, building owners, designers, contractors and others involved in decision making over building project should take proper actions on management of building materials to protect the society, reducing environmental impacts whilst ensuring economic growth for a sustainable future.

Less attention is given to address the problem in many parts of the world. Wilt et.al. (2011) identified construction and building as amongst the top sectors that critically require information on the potential life-cycle impacts of materials. The current information on building materials is inadequate and not specific enough. Most of the data and information on building materials that promoted "green and sustainable" construction and buildings can be confusing to builders and other users (Levin, 2010; Willem \& Singer, 2010). Builders and design professionals have difficulties to assess the available material options (Spiegel \& Meadows, 2010). There were too many types, brands and specifications with complicated written material properties.

Readily available building product labels concentrated more on the commercial and marketing features with limited information relating to health and effects to the environment. Several studies suggested that the issue of hazards and toxicity of construction and building materials can be disregarded because some legal acts and guidelines avoided setting very restrictive regulations to balance the public health and the economic impacts of a country. This is further supported from the reviews of existing regulations and guidelines that were not fully designed to encourage the usage of sustainable and green materials in building construction industries. Several studies suggested on the support of the governing policy tools including economic policies, regulations, information and partnerships to ensure positive actions for sustainable and green construction activities.

\subsection{Challenges of Achieving Greener Building Adaptation Project}

The building construction stakeholders including the public may be exposed to the adverse effects of hazardous and toxic building materials since there were insufficient guidelines and regulations that should protect them. There are more risks for building adaptation projects since the construction activities are more complex and dealt with many stakeholders including people working within the project site. The construction activities in building adaptation projects partially contributed to the consumption of around $30 \%$ raw materials and 
$40 \%$ of global energy, producing nearly $35 \%$ of carbon dioxide. Around $28 \%$ of the construction debris is turned into landfill materials. There were also issues on the quality of indoor air that showed traces of pollution, hazardous and toxic substances presence despite following legal regulations stipulated in the construction requirements (Sarigiannis \& Mucci, 2009; Wilt et al., 2011). The activities indicated unsustainable and non-green industry compared with any other economic activity.

Building adaptation projects are often carried out in limited and confined available spaces (Spillane et al., 2010) with unavailable or inaccurate information and data on an existing building (Ali, 2010). Workers and construction players are exposed to many unknown risks. They might be exposed to hazardous materials such as asbestos based products, high lead content in paint and carcinogenic dusts from demolition and cutting activities of decorative stones. Unfortunately, these existing building materials often lacked information (Strand \& Fossdal, 2003; Wilt et al., 2011) on toxic and hazardous contents, emissions associated to green house gas (GHG), carbon footprint, poor indoor air quality (IAQ) or energy usage, which also applied to new products and self-proclaimed green accredited materials.

There were also cases of irresponsible contractors who dumped illegal construction debris without knowing the exact contents of the building wastes. The act was harmful and dangerous not only to the environment, but to the people staying nearby. Contractors are often found to lack proper management of hazardous materials and the negligent actions have impacted human health, their social lives, the environment and the overall communities.

The construction activities posed threats not only to workers, consultants and clients but often tenants in the vicinity and nearby public. Studies revealed that safety notification systems to protect stakeholders from exposure to hazardous materials, dust and fumes are seldom installed on site or surrounding work place and safety measures are often not followed through (Ismail et al., 2009). Little information was found on hazardous and toxic exposures during demolition work in confined spaces. There is limited data and accessible information that can be accessed by the construction players as well as the public (Sarigiannis \& Mucci, 2009; Wilt et al., 2011). Some available data on health and safety are found to be conflicting. Studies on managing hazardous building materials are fragmented. Laird et al. (2011) suggested that some studies were theoretically vague and not well supported. Therefore, availability and accessibility of building materials information that could be understood by stakeholders is required. The information on building material will notify and also acts as a means of sharing information not only on the building materials physical contents, but also on the impacts to society, the environment and economy for a more sustainable and greener adaptation projects.

\subsection{The Way Forward for Building Material Management in Adaptation Projects}

Since the trends of green construction and sustainable construction have only begun to settle worldwide, the construction practices in building adaptation projects must also change from the conventional methods of operating. Availability of information on building materials particularly hazardous and toxic products and specific construction guidelines for protection to manage risk is required. The current Occupational Safety and Health Act do not protect 
those who are affected by the hazardous and toxic building materials and construction process. Medical and toxicological studies are also difficult to interpret as many studies are done separately to individual materials or components. In reality, there are numerous building materials found in a space that may be frequently used in a similar area and by similar users. It was also difficult to assess the effect of health and the exposure an individual received, as there were other influences from exposure or environmental factors. Required information might serve the growing interest of stakeholders to determine whether and how hazardous materials can impact TBL. It may be through a set of database that contained hazardous and toxic information, potential recyclability components and other required information for building adaptation projects.

Fig. 2 shows a proposed framework for Building Material Management for Greener Building Adaptation Projects outlining the basis for managing building materials throughout the process from initial planning until occupancy stages. This could be made possible with the aid of Information Technology (IT) that can provide alternative handling of all the required information on building materials in adaptation projects in a more rational way, compared with paper based data and records. The framework could be used to explore the possibilities of obtaining further information on the existing building to achieve green and sustainable construction practices that may result in greener building adaptation projects. This could point towards some topical questions pertaining to existing building and the adaptation process. How can the factors ensure successful project implementation? What are the precautions required to protect the neighbouring occupants and the surrounding environment? How much benefits that could be obtained from the project? There are many possible combinations of these parameters that suggest further research.

The Framework may include risk and safety management, guidelines for demolition, construction and maintenance management as well as health effects that could be made accessible. Manuals, warranties, common instructions, often considered as forgotten paper documents could also be made available. Availability and accessibility of the required information could assist the client and designers to produce accurate and complete designs as required. Risk management plan could also be produced prior to the construction work

\subsection{Conclusion}

The trend to respect older building through the process of building adaptation is on the rise. The construction activities involved in building adaptation are more complex and deal with existing building structure and materials. There is a growing demand for building materials as there are many opportunities for adaptation or redevelopment projects. Unfortunately, there are adverse impacts to sustainability and the green construction activities. Accessible and available information are required to ensure construction players understand and be aware of the impacts. The project's players such as the designers, client and contractors could integrate information on building material management. There is numerous information involved during building adaptation process, hence more research are required to explore the strength and opportunities to achieve greener building adaptation project. 


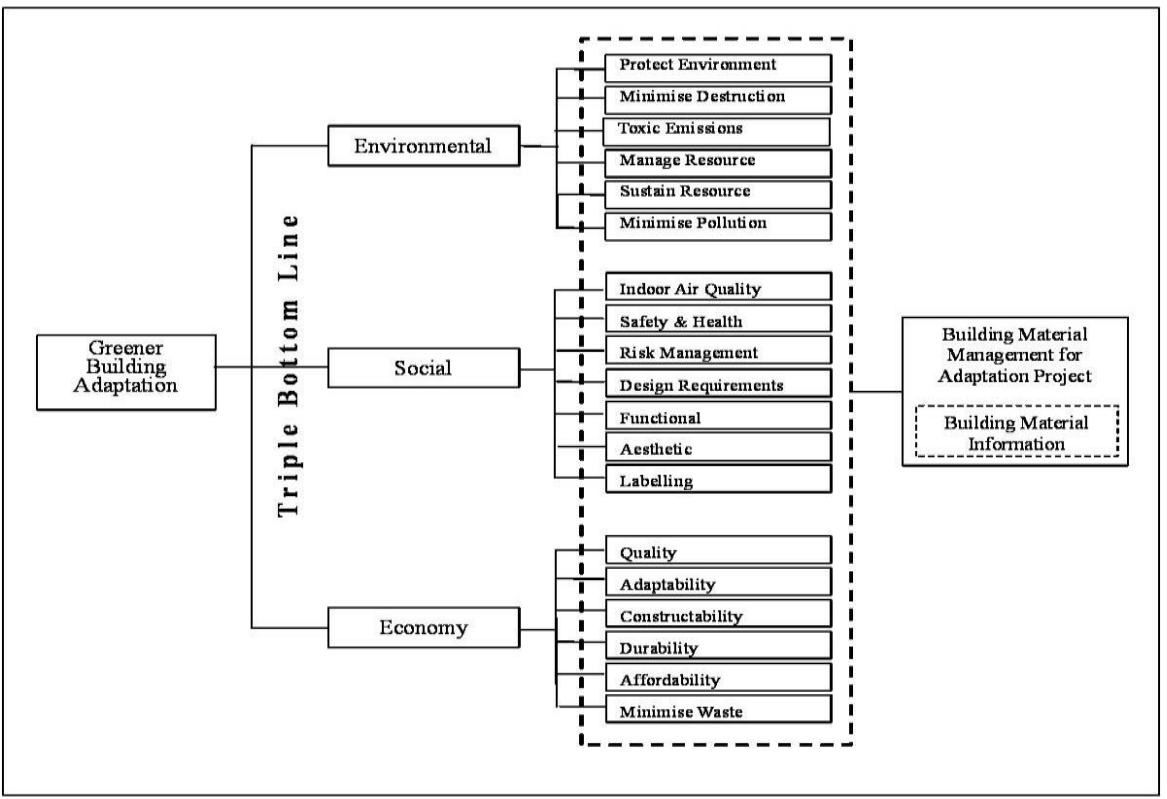

Figure 2: Framework for Building Material Management in Adaptation Projects

\section{Acknowledgement}

The authors would like to thank Research Management Institute of Universiti Teknologi MARA for supporting this research under the Excellence Research Grant scheme.

\section{References}

Ali, A. S. (2010). Design information in managing refurbishment projects in Malaysia. International Journal of the Physical Sciences, 5(6), 768-773. Retrieved from http://www.academicjournals.org//JPS

Betts, M., Graham, Robinson, Blake, N., Charles, Burton, \& Godden, D. (2011). Global Construction 2020.

CIB. (1999). Agenda 21 on sustainable construction - CIB report publication 237. Construction.

Douglas, J. (2006). Building Adaptation 2nd Edition. Building (pp. 1-47). Butterworth-Heinemann.

GBI-Research. (2010). Green buildings market to 2015 - incentives for green initiatives and minimum level of standards to boost growth opportunities. Construction (pp. 1-96).

Ismail, F., Hashim, A. E., Ismail, R., \& Majid, M. Z. A. (2009). The operationalisation of safety culture for the Malaysian construction organisations. International Conference Sustainable Building 2000Journal of Business and Management, 4(9), 226-237. 
Kibert, C. J., \& Grosskopf, K. (2006). Radical green buildings: Strategies for the next generation built environment. White Paper. Retrieved July 7, 2011, from www.cce.ufl.edu/WhitePaper-RSC06.pdf

Laird, I., Olsen, K., Harris, L., Legg, S., \& Perry, M. J. (2011). Utilising the characteristics of small enterprises to assist in managing hazardous substances in the workplace. International Journal of Workplace Health Management, 4(2), 140-163. doi:10.1108/17538351111143312

Levin, H. (2010). National programs to assess IEQ effects of building materials and products (pp. 1-50).

Sarigiannis, D. A., \& Mucci, N. (2009). Which health effects are associated to indoor air pollution ? Brussels. Retrieved July 7, 2011, from www.cair4health.eu/Final.../C4H_indoor air_Sarigiannis.pdf

Spiegel, R., \& Meadows, D. R. U. (2010). A guide to product selection and specification: Green building materials, 3rd edition. Construction (3rd ed.). John Wiley \& Sons, Inc., New York.

Spillane, J. P., Oyedele, L. O., Meding, J. K. V., \& Konanahalli, A. (2010). Material management within confined construction sites. COBRA 2010 - The Construction, Building and Real Estate Research Conference of the Royal Institution of Chartered Surveyors Held at Dauphine Université , Paris , 2-3 September 2010. Dauphine Université, Paris. Retrieved from www.rics.org/cobra

Strand, S. M. \& Fossdal, S. (2003). Do standards and regulations supply the necessary incentive for sustainable building? UNEP Industry And Environment, (September), 33-36.

Willem, H., \& Singer, B. C. (2010). Chemical emissions of residential materials and products : Review of available information.

Wilt, C. A., Monaco, J. K., Geibig, J. R., \& Hite, A. (2011). Identification and analysis of product/ chemicals exchange information within the building product sector. 